\title{
The development and reproduction of grape phylloxera (Daktulosphaira vitifoliae Fitch) strains of Hungarian vine-districts in root-bioassays
}

\author{
L. Tóth H., Horváthné Baracsi É. and Kocsis L. \\ University of Veszprém, Georgikon Faculty of Agricultural Sciences Department of Horticulture \\ H-8360Keszthely,Festeticsu7.E-mail:th@georgikon.hu; hbe@georgikon.hu; kocsis-l@georgikon.hu
}

Summary: The root bioassay method allows for 4-6 week continuous observation of grape phylloxera feeding on the grape root. 10 Hungarian phylloxera strains were compared on susceptible Vitis vinifera $\mathrm{cv}$. Chardonnay and the resistant rootstocks of $V$. berlandieri $x$ V. riparia Teleki $5 \mathrm{C}$ and $V$, berlandieri $x$ V. rupestris Georgikon 121 in in vitro observations. The strains originated from Villány and Eger (Figure 3 ) had higher reproduction on the root of V. berlandieri $x$ V. riparia Teleki 5C (201 and $119 \mathrm{eggs}$ ) and were more aggressive than the others (average production $10 \mathrm{eggs}$ ). The continuous high level of survival, development and reproduction of the Eger strain on Teleki $5 \mathrm{C}(\mathrm{V}$. berlandieri $x$ V.riparia) until day 46 may be due to adaptation.

Key words: Daktulosphaira vitifoliae FITCH, Vitis vinifera $\mathrm{ev}$. Chardonnay, V. berlandieri $x$ V. riparia Teleki 5C. V. berlandieri $x$ V. rupestris Georgikon 121, resistance, root bioassay

Grape phylloxera (Daktulosphaira vitifoliae Fitch), one of the most important grape pests lives on the leaves and roots of the vine. The insect was imported into Europe from North America with grapevine around 1860. In its rapid spread across Europe destroyed two-thirds of the vineyards of the continent.

Its life cycle has sexual and asexual phases with forms that feed from leaf and root galls. Specimens forming galls on leaves and on roots are called gallicolles and radicicoles respectively. The root galls are termed tuberosities, if they occur on mature-suberized roots. They are called nodosities when occurring near root tips.

Not all forms occur throughout the insect's range. Root forms predominate on Vitis vinifera cultivars. Leaf forms predominate on Vitis species characteristic to the NorthAmerican native range.

We have used vines grafted to rootstocks for a century in Europe. We hypothesize that over the century that rootstocks have been used phylloxera could adapt to thrive on rootstock roots and thereby express vine damage. We have noticed that grape phylloxera leafgalls are very common in viticultural regions of Hungary. This is due to rootstock foliage becoming widespread through the drying of vineyard scions and escape of rootstocks from vineyards to surrounding uncultivated land. The high population of sexually reproducing grape phylloxera that result from the abundance of rootstock's leaves may increase the insect's genetic variability and speed the adaptation process (Tóth, 2003). We therefore hypothesize that adaptation will occur relatively sooner in Hungary than in regions of the world where these conditions do not exist. We are testing this hypothesis through a survey of phylloxera in Hungary assayed for virulence on selected root types. We were particularly interested in two rootstocks with Vitis berlandieri parentage because of the wide usage of these cultivars in rootstocks around the world.

\section{Material and method}

The research was conducted at the Research Farm of the Department of Horticulture Veszprém University of Agricultural Sciences at Keszthely. Eggs of phylloxera were collected from galls of rootstocks in vineyards of ten Hungarian vine districts (Map l.). Two generations were cultured on $V$. vinifera roots before testing. Assay was done with 3-5 $\mathrm{mm}$ diameter mature roots obtained from Kaszás nursery, Zalaegerszeg (Vitis vinifera $c v$. Chardonnay) and from Cserszegtomaj (V. berlandieri $x V$. riparia Teleki $5 \mathrm{C}$, $V$. berlandieri $x V$. rupestris Georgikon 121).

Our experiment was established according to the root bioassay method of de Benedictis \& Granett (1992) \& Kocsis et al. (1997). The eggs were collected at 6 day intervals for infestation. Assay roots were washed with tap water and then rinsed with distilled water. We used $10 \mathrm{~cm}$ diameter Petri dishes, in which 2 pieces of $8 \mathrm{~cm}$ long roots were placed. We prepared cotton wool in distilled water and then coiled it on each freshly cut root end. 10 phylloxera eggs were placed on each root.

The number of phylloxera adults, developmental forms and eggs were counted on days 12, 18, 32, 39 and 46 after infection. The number of phylloxera eggs increased rapidly from the $18^{\text {th }}$ day. The reproduction of the pest was very intensive. A diagram was constructed on the $12^{\text {th }}$ day from 


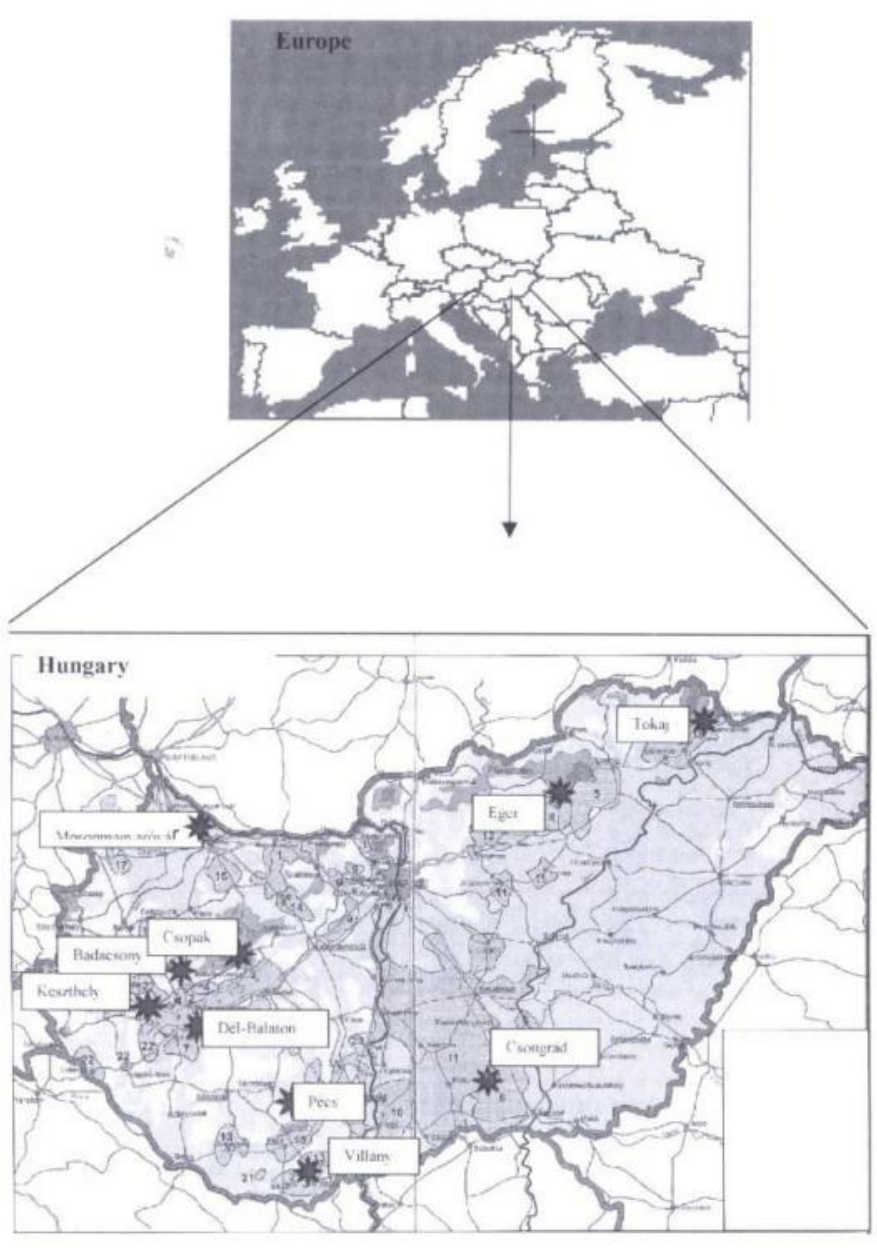

Map 1 title The phylloxera strains from 10 Hungarian vine districts

the phylloxera nymph 1-2 stage and on the $18^{\text {th }}$ day from the phylloxera nymph 3-4 stage. Data were analyzed by oneway ANOVA and means were compared by LSD test. The t test probe was applied to all pairs to be compared as group means. The significance level was $\lambda=0.05$. The filed resistance of Teleki $5 \mathrm{C}$ was observed because of the results of bioassays. The damage of phylloxera was showed on the field wines on Teleki $5 \mathrm{C}$ in Eger. 10 heavily infected vine leaves were sampled from vines. The numbers of phylloxera were counted on the roots and the yield production was measured.

\section{Results}

Individuals from all the strains survived after egg hatch till the $12^{\text {th }}$ day (Figure 1 ). In the beginning the survival of nymphs of the Csongrád, Badacsony and Dél-Balaton strains was better than that of the others (Table 1), the statistical analysis showed that the Eger strain was significantly different from any. The number of nymphs was significantly higher for the Eger (Table 2) and the Csongrád strains on the $18^{\text {th }}$ and $25^{\text {th }}$ day respectively. The number of adults was significantly different for Badacsony, Tokaj and Eger strains on the $25^{\text {th }}$ day (Table 3 ), for Badacsony and Csongrád

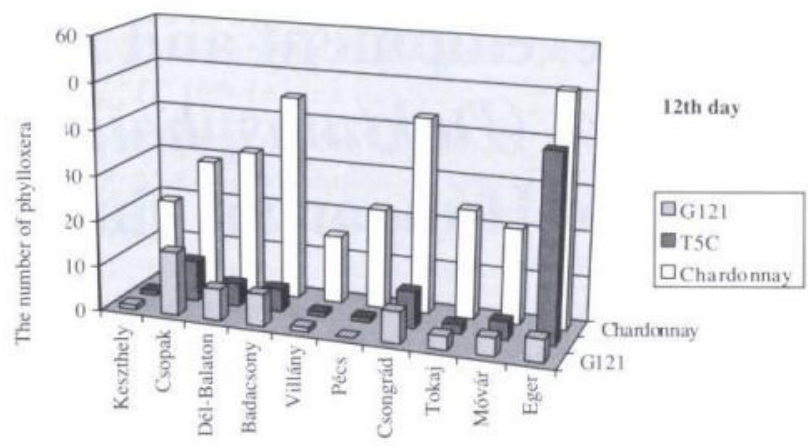

Figure $I$ The number of 1st stage phylloxera nymph on root pieces (Georgikon 121, Teleki 5C, and Chardonnay) on the $12^{\text {th }}$ day.

Tables 1-6 Counts of individuals of the pest according to developmental stages at different sampling dates.

\begin{tabular}{|l|c|}
\hline Table I & $12^{\text {th }}$ day \\
\hline Cultivar & $1^{\text {st }} \mathrm{Nymph}$ \\
\hline Chardonnay & $3.00 \mathrm{a}$ \\
\hline T5C & $0.81 \mathrm{~b}$ \\
\hline G121 & $0.50 \mathrm{~b}$ \\
\hline
\end{tabular}

\begin{tabular}{|l|c|}
\hline Strain & Nymph 1-2 \\
\hline Keszthely & $0.70 \mathrm{~b}$ \\
\hline Csopak & $1.57 \mathrm{~b}$ \\
\hline Dél-Balaton & $1.47 \mathrm{~b}$ \\
\hline Badacsony & $1.87 \mathrm{~b}$ \\
\hline Villány & $1.47 \mathrm{~b}$ \\
\hline Pécs & $0.77 \mathrm{~b}$ \\
\hline Csongrád & $1.93 \mathrm{ab}$ \\
\hline Tokaj & $0.77 \mathrm{~b}$ \\
\hline Móvár & $1.23 \mathrm{~b}$ \\
\hline Eger & $3.23 \mathrm{a}$ \\
\hline
\end{tabular}

\begin{tabular}{|l|c|c|}
\hline Table 2 & \multicolumn{2}{|c|}{18 th day } \\
\hline Cultivar & 1st Nymph & 2nd Nymph \\
\hline Chardonnay & $1.31 \mathrm{a}$ & $1,11 \mathrm{a}$ \\
\hline T5C & $0.11 \mathrm{~b}$ & $0,10 \mathrm{~b}$ \\
\hline G121 & $0.05 \mathrm{~b}$ & $0,04 \mathrm{~b}$ \\
\hline
\end{tabular}

\begin{tabular}{|l|c|c|}
\hline Strain & 1st Nymph & 2nd Nymph \\
\hline Keszthely & $0.40 \mathrm{ab}$ & $0.30 \mathrm{~b}$ \\
\hline Csopak & $0.60 \mathrm{ab}$ & $0.47 \mathrm{ab}$ \\
\hline Dél-Balaton & $0.73 \mathrm{a}$ & $0.27 \mathrm{~b}$ \\
\hline Badacsony & $0.57 \mathrm{ab}$ & $0.70 \mathrm{ab}$ \\
\hline Villány & $0.00 \mathrm{~b}$ & $0.50 \mathrm{ab}$ \\
\hline Pécs & $0.10 \mathrm{~b}$ & $0.43 \mathrm{ab}$ \\
\hline Csongrád & $0.63 \mathrm{a}$ & $0.33 \mathrm{~b}$ \\
\hline Tokaj & $0.20 \mathrm{~b}$ & $0.73 \mathrm{ab}$ \\
\hline Móvár & $0.13 \mathrm{~b}$ & $0.67 \mathrm{ab}$ \\
\hline Eger & $0.35 \mathrm{ab}$ & $0.87 \mathrm{a}$ \\
\hline
\end{tabular}




\begin{tabular}{|l|c|c|c|c|}
\hline Table 3 & \multicolumn{4}{|c|}{$25^{\text {th }}$ day } \\
\hline Cultivar & $1^{\text {st }}$ Nymph & $2^{\text {nd }}$ Nymph & Adult & Egg \\
\hline Chardonnay & 0.21 & 0.99 & 0.87 & $13.69 \mathrm{a}$ \\
\hline T5C & 0 & 0.06 & 0.13 & $2.51 \mathrm{~b}$ \\
\hline G121 & 0.04 & 0.03 & 0.03 & $0.13 \mathrm{~b}$ \\
\hline
\end{tabular}

\begin{tabular}{|l|c|c|}
\hline Table 6 & \multicolumn{2}{|c|}{$46^{\text {th }}$ day } \\
\hline Cultivar & Adult & Egg \\
\hline Chardonnay & $0.82 \mathrm{a}$ & $15.14 \mathrm{a}$ \\
\hline T5C & $0.10 \mathrm{a}$ & $4.37 \mathrm{~b}$ \\
\hline G121 & $0.01 \mathrm{a}$ & $0.10 \mathrm{~b}$ \\
\hline
\end{tabular}

\begin{tabular}{|l|c|c|c|c|}
\hline Strain & $1^{\text {st }}$ Nymph & $2^{\text {nd }}$ Nymph & Adult & Egg \\
\hline Keszthely & $0.10 \mathrm{a}$ & $0.20 \mathrm{~b}$ & $0.31 \mathrm{ab}$ & $3.86 \mathrm{a}$ \\
\hline Csopak & $0.10 \mathrm{a}$ & $0.30 \mathrm{~b}$ & $0.50 \mathrm{ab}$ & $5.07 \mathrm{a}$ \\
\hline Dél-Balaton & $0.10 \mathrm{a}$ & $0.20 \mathrm{~b}$ & $0.07 \mathrm{~b}$ & $0.53 \mathrm{a}$ \\
\hline Badacsony & $0.13 \mathrm{a}$ & $0.63 \mathrm{~b}$ & $0.67 \mathrm{a}$ & $6.17 \mathrm{a}$ \\
\hline Villíny & $0.10 \mathrm{a}$ & $0.27 \mathrm{~b}$ & $0.30 \mathrm{ab}$ & $7.73 \mathrm{a}$ \\
\hline Pécs & $0.00 \mathrm{a}$ & $0.20 \mathrm{~b}$ & $0.30 \mathrm{ab}$ & $3.37 \mathrm{a}$ \\
\hline Csongrád & $0.00 \mathrm{a}$ & $0.77 \mathrm{a}$ & $0.00 \mathrm{~b}$ & $1.00 \mathrm{a}$ \\
\hline Tokaj & $0.00 \mathrm{a}$ & $0.23 \mathrm{~b}$ & $0.60 \mathrm{a}$ & $5.83 \mathrm{a}$ \\
\hline Móvár & $0.00 \mathrm{a}$ & $0.37 \mathrm{ab}$ & $0.30 \mathrm{ab}$ & $3.87 \mathrm{a}$ \\
\hline Eger & $0.00 \mathrm{a}$ & $0.37 \mathrm{ab}$ & $0.63 \mathrm{a}$ & $7.43 \mathrm{a}$ \\
\hline
\end{tabular}

\begin{tabular}{|l|l|c|}
\hline Strain & Adult & Egg \\
\hline Keszthely & $0.23 \mathrm{ab}$ & $1.83 \mathrm{~b}$ \\
\hline Csopak & $0.17 \mathrm{~b}$ & $4.47 \mathrm{ab}$ \\
\hline Dél-Balaton & $0.23 \mathrm{ab}$ & $3.17 \mathrm{~b}$ \\
\hline Badacsony & $0.33 \mathrm{ab}$ & $6.87 \mathrm{ab}$ \\
\hline Villány & $0.27 \mathrm{ab}$ & $3.33 \mathrm{~b}$ \\
\hline Pécs & $0.13 \mathrm{~b}$ & $1.27 \mathrm{~b}$ \\
\hline Csongrád & $0.60 \mathrm{a}$ & $18.07 \mathrm{a}$ \\
\hline Tokaj & $0.50 \mathrm{ab}$ & $7.60 \mathrm{ab}$ \\
\hline Móvár & $0.17 \mathrm{~b}$ & $3.33 \mathrm{~b}$ \\
\hline Eger & $0.31 \mathrm{ab}$ & $15.43 \mathrm{a}$ \\
\hline
\end{tabular}

\begin{tabular}{|l|c|c|c|}
\hline Table 4 & $32^{\text {nd }}$ day \\
\hline Cultivar & Nymph & Adult & Egg \\
\hline Chardonnay & 0.21 & $1.48 \mathrm{a}$ & $27.7 \mathrm{a}$ \\
\hline T5C & 0 & $0.21 \mathrm{~b}$ & $6.65 \mathrm{~b}$ \\
\hline G121 & 0 & $0.03 \mathrm{~b}$ & $1.00 \mathrm{~b}$ \\
\hline
\end{tabular}

\begin{tabular}{|l|c|c|c|}
\hline Strain & Nymph & Adult & Egg \\
\hline Keszthely & $0.07 \mathrm{a}$ & $0.40 \mathrm{~b}$ & $26.7 \mathrm{a}$ \\
\hline Csopak & $0.13 \mathrm{a}$ & $0.60 \mathrm{ab}$ & $6.20 \mathrm{ab}$ \\
\hline Dél-Balaton & $0.10 \mathrm{a}$ & $0.20 \mathrm{~b}$ & $2.23 \mathrm{~b}$ \\
\hline Badacsony & $0.13 \mathrm{a}$ & $1.03 \mathrm{a}$ & $12.83 \mathrm{ab}$ \\
\hline Villány & $0.03 \mathrm{a}$ & $0.43 \mathrm{ab}$ & $10.53 \mathrm{ab}$ \\
\hline Pécs & $0.07 \mathrm{a}$ & $0.37 \mathrm{~b}$ & $5.70 \mathrm{ab}$ \\
\hline Csongrád & $0.03 \mathrm{a}$ & $0.90 \mathrm{a}$ & $11.17 \mathrm{ab}$ \\
\hline Tokaj & $0.07 \mathrm{a}$ & $0.63 \mathrm{ab}$ & $14.33 \mathrm{ab}$ \\
\hline Móvár & $0.07 \mathrm{a}$ & $0.43 \mathrm{ab}$ & $8.80 \mathrm{ab}$ \\
\hline Eger & $0.00 \mathrm{a}$ & $0.73 \mathrm{ab}$ & $19.50 \mathrm{ab}$ \\
\hline
\end{tabular}

\begin{tabular}{|l|c|c|c|}
\hline Table 5 & Nymph & Adult & Egg \\
\hline Cultivar & $0.01 \mathrm{a}$ & $1.32 \mathrm{a}$ & $23.58 \mathrm{a}$ \\
\hline Chardonnay & $0 \mathrm{a}$ & $0.15 \mathrm{~b}$ & $6.40 \mathrm{~b}$ \\
\hline T5C & $0 \mathrm{a}$ & $0.01 \mathrm{~b}$ & $0.10 \mathrm{~b}$ \\
\hline G121
\end{tabular}

\begin{tabular}{|l|c|c|c|}
\hline Strain & Nymph & Adult & Egg \\
\hline Keszthely & $0.00 \mathrm{~b}$ & $0.30 \mathrm{a}$ & $8.67 \mathrm{ab}$ \\
\hline Csopak & $0.00 \mathrm{~b}$ & $0.50 \mathrm{a}$ & $8.00 \mathrm{ab}$ \\
\hline Dél-Balaton & $0.03 \mathrm{a}$ & $0.27 \mathrm{a}$ & $2.90 \mathrm{~b}$ \\
\hline Badacsony & $0.00 \mathrm{~b}$ & $0.73 \mathrm{a}$ & $16.33 \mathrm{a}$ \\
\hline Villány & $0.00 \mathrm{~b}$ & $0.30 \mathrm{a}$ & $7.43 \mathrm{ab}$ \\
\hline Pécs & $0.00 \mathrm{~b}$ & $0.30 \mathrm{a}$ & $3.80 \mathrm{~b}$ \\
\hline Csongrád & $0.00 \mathrm{~b}$ & $0.79 \mathrm{a}$ & $13.10 \mathrm{ab}$ \\
\hline Tokaj & $0.00 \mathrm{~b}$ & $0.66 \mathrm{a}$ & $15.00 \mathrm{ab}$ \\
\hline Móvár & $0.00 \mathrm{~b}$ & $0.37 \mathrm{a}$ & $6.17 \mathrm{ab}$ \\
\hline Eger & $0.00 \mathrm{~b}$ & $0.70 \mathrm{a}$ & $18.53 \mathrm{a}$ \\
\hline
\end{tabular}

strains on the $32^{\text {nd }}$ day and for Csongrád strain on the $46^{\text {th }}$ day. The highest number of eggs was produced on the $25^{\text {th }}$ day by the Villány, Tokaj and Eger strains, but it was not significantly different from any (Table 3 ). Significantly higher number of eggs was on the $32^{\text {nd }}$ day at Keszthely (Table 4), on $39^{\text {th }}$ day at Badacsony and Eger (Table 5), on the $46^{\text {th }}$ day at Csongrád and Eger strains (Table 6).

In addition, the reproduction was higher in populations on Chardonnay roots than in those on Teleki $5 \mathrm{C}$ and Georgikon 121. The statistical analysis of the strain reproduction showed that the Vitis vinifera $\mathrm{cv}$. Chardonnay was significantly different from bath $V$. berlandieri $x V$. riparia. Teleki $5 \mathrm{C}$, and $V$. berlandieri $x V$. rupestris Georgikon 121 .

We have found a viable, reproducing population on Teleki $5 \mathrm{C}$ roots in Eger causing tuberosities. The yield production results reflect the damage (Table 7), but we should follow the vine for a couple of years to confirm the results.

\section{Discussion}

This study investigated the survival, development and reproduction of ten Hungarian phylloxera strains on excised roots in laboratory bioassays. This is a rapid technique, which is independent on the season and requires less space than tests with whole plants.

This in vitro system for grape with phylloxera readily allows the observation and qualification of phylloxera resistance. Phylloxera feeding on the roots of resistant cultivars was described by Granett et al. (2001) \& Kocsis et al. (1999, 2000). King et al. (1982) observed the development of phylloxera on root of $V$. berlandieri $x \mathrm{~V}$. riparia SO4. Forneck et al. (1996) found dead roots on V. berlandieri $x V$. riparia Teleki $5 \mathrm{BB}, V$. berlandieri $x \mathrm{~V}$. riparia SO4 and Porten \& Smith (2000) on the root of $V$. berlandieri $x \mathrm{~V}$. riparia Teleki $5 \mathrm{C}$ was associated with phylloxera presence. In all cases populations were limited in 
Table 7

\begin{tabular}{|c|c|c|c|c|c|c|}
\hline \multicolumn{7}{|c|}{ Variety: Bianca / V. berlandieri x V. riparia T5C (Eger, 2003) } \\
\hline Sample no. & Column no. & $\begin{array}{l}\text { Number of } \\
\text { vinestocks }\end{array}$ & $\begin{array}{l}\text { Number of } \\
\text { clusters/stock }\end{array}$ & $\begin{array}{l}\text { Weight of cluster } \\
\mathrm{kg} / \mathrm{stock}\end{array}$ & Brix ${ }^{\mathrm{e}}$ & $\begin{array}{c}\text { Number of } \\
\text { phylloxera eggs }\end{array}$ \\
\hline 16 & 1. & 6 & no data & no data & no data & 119 \\
\hline 2 & VI. & 2 & no data & no data & no data & 132 \\
\hline 3 & $\mathrm{XI}$. & 4 & 25 & 2,2 & 22,4 & 3 \\
\hline 4 & XVI. & 4 & 19 & 2,4 & 23.2 & 19 \\
\hline 5 & $\mathrm{XXI}$ & 4 & 24 & 2 & 22,3 & 23 \\
\hline 6 & I. & 5 & no data & no data & no data & 3 \\
\hline 7 & VI. & 5 & 1 & 1.4 & 22,1 & 17 \\
\hline 8 & $\mathrm{XI}$. & 3 & 23 & 2,8 & 22,4 & 0 \\
\hline 9 & XVI. & 2 & 32 & 3,5 & 22,8 & 4 \\
\hline 10 & XXI. & 2 & 35 & 3,4 & 22.2 & 24 \\
\hline
\end{tabular}

size and predominated on immature roots. In the case of field vines, no significant root damage was seen.

The phylloxera population in Europe is very variable Forneck et al. (2000). We observed the development of the phylloxera on the root of $V$. berlandieri $x V$. riparia Teleki 5C. The high level of survival, development and reproduction of the Eger strain on Teleki $5 \mathrm{C}$ ( $V$. berlandieri $x V$. riparia) may be due to adaptation. These interpretations suggest the need to test the prediction that such adaptation will lead to vine damage in the field. An alternative interpretation is that vigor in Petri dish bioassays is not due to adaptation but a variability that is seen only on excised roots or on immature roots or on callus and is conclusions for field work can not be. Future tests deducted from that need to be done to disprove one or the other of these hypotheses. In particular, finding Teleki 5C field damage in Eger would support the first interpretation whereas not finding field damage in Eger would support the second (Table 7).

\section{Conclusion}

Hungarian phylloxera strains are different by development, reproduction and longevity of survival in root-bioassay.

In this study the Eger strain reproduced well not only on Chardonnay roots but on Teleki $5 \mathrm{C}(\mathrm{V}$. berlandieri $x \mathrm{~V}$. riparia) roots too. It was significantly different from all others on the $12^{\text {th }}$ (by nymph), the $18^{\text {th }}$ (by nymph), the $25^{\text {th }}$ (by adult), the $39^{\text {th }}$ (by egg) and the $46^{\text {th }}$ (by egg) days. It seems that the strain from Eger is the most aggressive in Hungary.

A similar situation was recognized in the Rheingau region of Germany on $V$, berlandieri $x V$. riparia rootstocks in the late 1980 's. Porten et al (2000) mentioned that phylloxera damage has become more frequent in several regions in Germany.

It is very interesting that the strain from Villány developed well only on the root of rootstocks (Figure 3), however the mean was not significantly different from any other (Table 3). In the beginning the Csongrád strain showed little progress (Figure 2, Figure 3) and then rapidly reproduced eggs (Figure 5, Figure 6). This strain reproduced the most eggs on the $46^{\text {th }}$ day.

In addition the Csongrád strain, the Eger and Villány strains and the Badacsony and Villány strains developed well on the roots of Vitis vinifera $c v$. Chardonnay, $V$. berlandieri $x V$. riparia Teleki $5 \mathrm{C}$ and $V$. berlandieri $x$ V. rupestris Georgikon 121, respectively. These strains could reproduce and develop rapidly and may cause damage in the field.

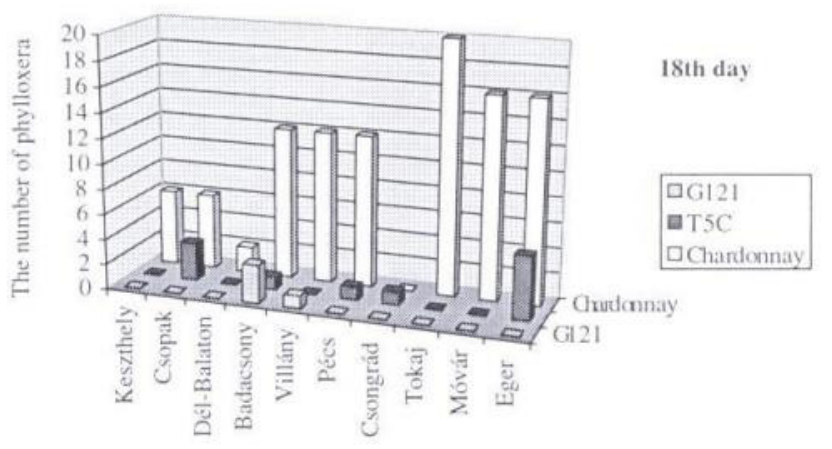

Figure 2 The number of $2^{\text {nd }}$ stage phylloxera nymph on root pieces (Georgikon 121. Teleki 5C, and Chardonnay) on the $18^{\text {th }}$ day.

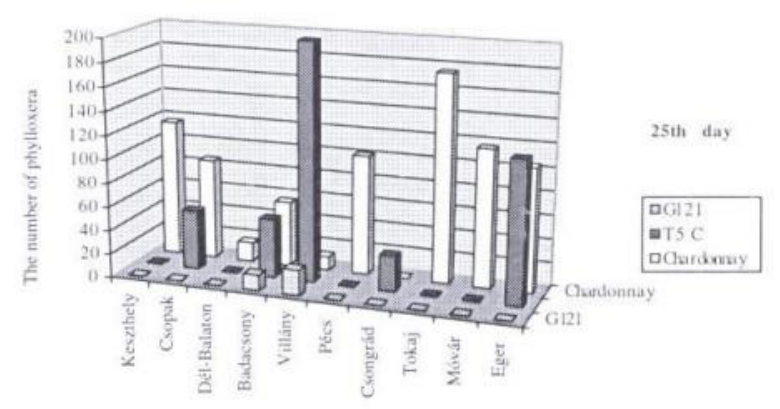

Figure 3 The number of phylloxera eggs on root pieces (Georgikon 121, T5C, and Chardonnay) on the 25th day. 


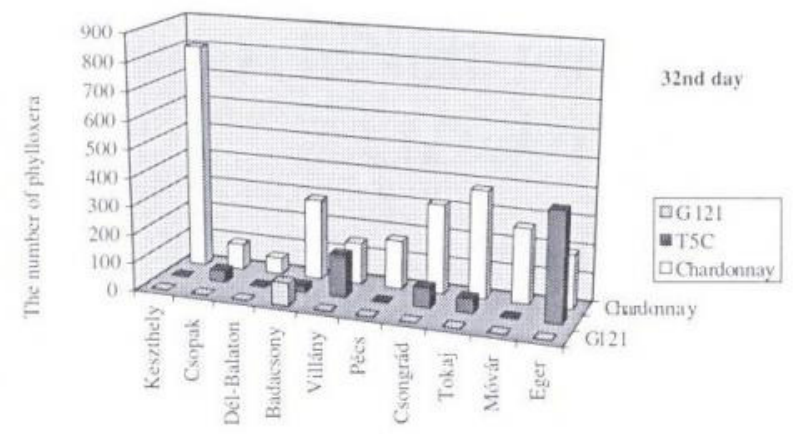

Figure 4 The number of phylloxera eggs on root pieces (Georgikon 121. Teleki 5C, and Chardonnay) on the 32nd day.

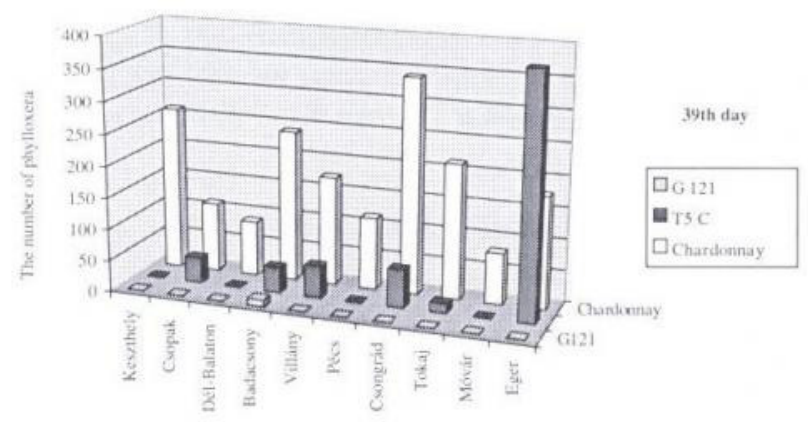

Figure 5 The number of phylloxera eggs on root pieces (Georgikon 121, T5C, \& Chardonnay) on the 39th day.

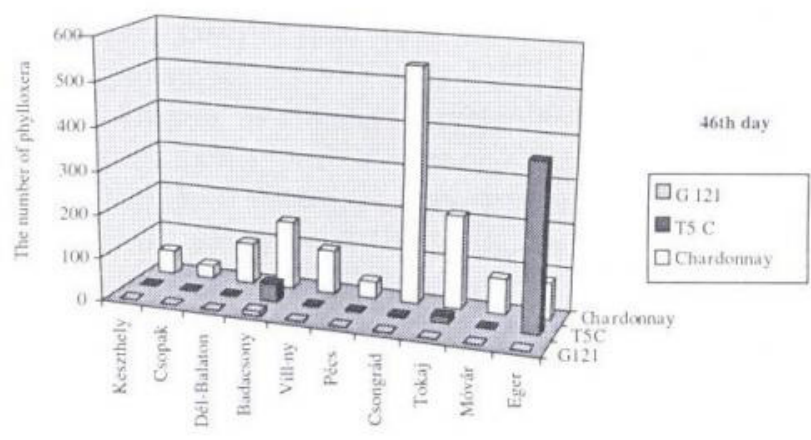

Figure 6 The number of phylloxera eggs on root pieces (Georgikon 121, Teleki 5C. \& Chardonnay) on the 49th day.

\section{Acknowledgements}

The authors would like to thank the financial support of the Hungarian Ministry of Agriculture. Special thanks are due to $M$. Andrew Walker \& Jeffrey Granett University of California for reviewing the manuscript.

\section{References}

De Benedictis, J.A \& Granett, J. (1992): Variability of responses of grape phylloxera to bioassays that discriminate between California biotypes. Journal of Economic Entomology 85, 1527-1534.

Forneck, A., Walker, M. A. \& Merkt, N. (1996): Aseptic dual culture of grape (Vitis spp.) and grape phylloxera (Daktulosphaira vitifoliae Fitch). Vitis 35, 95-97.

Forneck, A., Walker, M.A. \& Blaich, R. (2000): Genetic structure of an introduced pest, grape phylloxera (Daktulosphaira vitifoliae Fitch) in Europe. Genome 43, 669-678.

Granett, J., Walker, M.A., Kocsis, L. \& Omer, A.D. (2001): Biology and Management of Grape Phylloxera Annu. Rev. Entomol. 46, 387-412.

King, P.D., Meekings, J.S. \& Smith, S.M. (1982): Studies of the resistance of grapes to phylloxera. NZ J. Exp. Agricult. 10, 337-344.

Kocsis, L., Lin, H., Granett, J., Omer, A. D. \& Walker, M. A. (1997): Variability of grape phylloxera in Hungary. Horticultural Science - Kertészeti Tudomány. 3-4., 73-77.

Kocsis, L., Granett, J., Omer, J., Walker, M. A. \& Lin, H. (1999): Grape Phylloxera Populations Adapted to Vitis berlandieri X Vitis riparia rootstocks, American Journal of Enol. Vitic. 50, 101-106.

Kocsis, L., Horvath, L., Kozma, P. \& Pinter, Cs. (2000): Grape cultivars and phylloxera isolate as two factors of vine susceptibility in Hungary. The International Symposium on Grapevine Phylloxera Management, Melbourne, Australia (Agriculture Victoria, Rutherglen) pp. 69-79.

Porten, M. \& Smith, J. (2000): Current problems with phylloxera on grafted vines in Germany and ways to fight them. The international symposium on grapevine phylloxera management, Melbourne, Australia (Agriculture Victoria, Rutherglen) pp. 89-98.

Tóth, H. \& Kocsis, L. (2003): Level of phylloxera resistance of two new rootstocks hybrids: Georgikon 28 and Georgikon 121. Proceedings of the VIII ${ }^{\text {th }}$ International Conference of Grape Genetics and Breeding, Kecskemét, Hungary (Van Damme-Beke, Belgium) pp. 739-742. 